\title{
Conceptuals Understanding: As The Effect of Reciprocal Teaching Assisted By Macromedia Flash
}

\author{
Ahmad Dliyaul Haq ${ }^{1}$, I Gusti Putu Suryadarma ${ }^{2}$ \\ \{ahmad.dliyaul22.2017@student.uny.ac.id ${ }^{1}$, samodhaya@yahoo.com² ${ }^{2}$ \\ 1,2Universitas Negeri Yogyakarta, Jl. Colombo No. 1, Karang Malang, caturtunggal, Kec. Depok, \\ Kabupaten Sleman, Daerah Istimewa Yogyakarta, Indonesia 55281
}

\begin{abstract}
Based on the observation, conceptuals understanding of student in SMA N 1 Jetis still need to be improved. This study aims to determine the effect of reciprocal teaching assisted by macromedia flash on understanding concepts in ecological material. This designe of this research was quasi-ekspeimental which used 2 groups, class X IPA 1 as the experimental group and class X IPA 5 as the control class. The result showed that eksperimental group was 0,38 (moderate) and The control group was 0,16 (low) from NGain value. As for the independent simple t-test analysis was $0,000<0,05$ were significant differences between control and experimental class on the value of conceptual understanding. The conclusion of this study is that Reciprocal Teaching assisted by Macromedia Flash has an effect on conceptuals understanding of student.
\end{abstract}

Keywords: conceptual understanding, effect, macromedia flash, reciprocal teaching

\section{Introduction}

In the 21 st century, the development of all fields is progressing very rapid, both in terms of science and technology. In order to keep up with the development progress, it is important to develop in the world of education. This is because education is an important component for developing potential or human resources. Developments in education can be marked by curriculum changes. Curriculum changes are made so that the quality of the learning system can keep up with developments so that future needs can be met. The curriculum used is the K13 curriculum in which it supports student-centered learning where students are more active in learning activities so that they are able to achieve success in learning.

The success learning factor that must be achieved is understanding the concept of the material that is being taught. Understanding concepts in students is characterized by being able to build meaning from learning messages, whether oral, written or electronic. Understanding concepts to students is identified as the ability of students to interpret, model, clarify, summarize, conclude, compare and explain[1]. A student is accustomed to gain understanding through experience of the characteristics possessed and not possessed from a group of objects. Students are encouraged to be able to grasp the understanding of a concept through observation of examples and not examples [2]. Understanding the concept becomes very important because it reflects the competencies that can direct students to become competent in various sciences. Dimension understanding of the concept according to [3].includes factual and procedural 
knowledge, connections, knowledge transfer and Metacology. So, understanding the concept is very necessary to obtain mastered the material so that it can get good learning outcomes in school.

One of Biology scopes taught at school is Ecology material which in this material includes several things that must be studied namely the ecosystem component, energy flow and biogeochemical cycle (Permendikbud Number 22 of 2016). Ecology material that is taught in schools is inseparable from natural events therefore to get good results in learning it is necessary to understand the concepts of why these events can occur.

The problem that often arises in learning is because it is still not entirely centered to students. One of them is caused by the method used by a teacher that still cannot support students to be more active during the learning process so that the learning outcomes obtained are still low. Whereas, the activeness of students in learning can help students to obtain a good understanding. [4] the relationship of activity with learning achievement has a significant effect, the more students being active, the higher the learning achievement. Besides, the teacher can also use technology or use learning media as a tool to deliver a material, so that it will facilitate students in understanding and increasing student interest in the material being taught. Based on observations at SMA N 1 Jetis, in learning biology there is still a need for methods and learning media that can help students to better understanding in the material presented. Learning which is carried out outside the classroom often faces several obstacles including the difficulty of conditioning students to study, limited by time and place

The teacher's role in teaching is very necessary, a teacher has to be able to help students to gain knowledge and solve problems. One of the methods in teaching is using learning models and media that can make students more interested and easier to understand about the material being taught. According to [5] Learning model is a systematic procedure or pattern that is used as a direction to achieve learning objectives in which there are strategies, techniques, methods, materials, media and learning assessment tools. While learning media according to [6] is a tool to convey information about what is taught to students so that the information can be received correctly. [7] states that, the function of media in education is to clarify the presentation of messages, overcome the limitations of space and time, increase students 'enthusiasm for learning, overcome students' passive attitudes and provide the same perception of subject matter. One of the models and media that can be used in learning activities is the reciprocal teaching and macromedia flash models. Learning by using this model can help students to play an active role during learning activities in class. Reciprocal teaching is one model that can improve reading comprehension, where learning is aimed at encouraging students to develop their skills [8].There are four special techniques in this model, namely, predicting, question generation, summarizing, and clarifying [9]. Reciprocal teaching is one way for a student to be able to understand an idea through reading text. In the reciprocal teaching model using four techniques including, predicting (guessing what will be learned and what will be asked by other groups), question generation (making questions about material not yet understood), summarizing (summarizing readings and processing them in their own language and clarifying (answering questions that have been given). [10]. The advantages of learning using the Reciprocal Teaching model include, can develop student creativity, foster cooperation between students, foster student talent, especially in speaking and developing attitudes, students pay more attention to lessons because they live themselves, cultivate the courage to think and speak in front of the class, train students to analyze problems and draw conclusions in a short time [11].

In addition, the use of macromedia flash as a learning medium can help students because this application can use various forms of animation, images and videos so that students are able 
to use auditory and visual abilities to improve their conceptual understanding. Macromedia flash is a multimedia application that contains animations or videos that can be used as media for teaching materials and presentations in learning process activities [12]. In addition, this media can also increase student interest in learning, this is because Macromedia Flash is able to display an event that is difficult to see directly. Through this macromedia flash events that occur can be displayed via video or animation. Some research that has been done shows that macromedia flash can improve students' understanding of concepts. [13] states that learning using macromedia flash as a teaching medium is able to increase students' conceptual knowledge compared to learning without using media as teaching aids. [14] states that macromedia flash is effective for improving conceptual understanding and student learning interest for the better. Based on the explanation, the researcher conducted a research on the effectiveness of the Macromedia Flash-assisted reciprocal teaching model on students' conceptual understanding.

\section{Method}

The study was conducted at SMA N 1 Jetis in July-2019. The type of the research is a quasiexperiment employing Pretest-Posttest Control-Group Design. The population of the study is $\mathrm{X}$ IPA class. The sample taken was X IPA 1 class which consisted of 32 students as the experimental class and X IPA 5 class which consisted of 32 students as the control class. The sampling technique used in this study was cluster random sampling. Data collection techniques used were documentation (in the form of pictures or photographs) and the delivery of tests used the concept understanding test instrument. The data analysis to measure the level of improvement in students' understanding employed the concepts of N-Gain

$$
<g>=\frac{\text { Spost-Spre }}{100-\text { Spre }}
$$

Description:

$$
\begin{array}{ll}
\text { Spost } \quad \text { : score of post test } \\
\text { Spre } \quad \text { score pretest }
\end{array}
$$

Then the results of the $\mathrm{N}$-gain calculation are interpreted in the following categories:

Table 1. N-gain criteria

\begin{tabular}{cc}
\hline N-gain & Interpretation \\
\hline $\mathbf{g} \geq \mathbf{0 , 7}$ & High \\
$\mathbf{0 , 3} \leq \mathbf{g}<\mathbf{0 , 7}$ & Medium \\
$\mathbf{g}<\mathbf{0 , 3}$ & Low \\
\hline
\end{tabular}

After the $\mathrm{N}$-gain test is performed, then to test whether there is a significant difference between the experimental class and the control class, the t-test is carried out, namely the independent sample t-test 


\section{Result and Discussion}

Recapitulation of the test results of the concept understanding test,

Table 2. Table value of understanding concept test results

\begin{tabular}{|c|c|c|c|c|}
\hline Description & \multicolumn{2}{|c|}{ Experiment Class } & \multicolumn{2}{|c|}{ Control Class } \\
\hline & Pretest & Posttest & Pretest & Posttest \\
\hline Average & 66.79 & 79.59 & 65.23 & 70.93 \\
\hline Maximum Score & 87.5 & 87.5 & 80 & 82.5 \\
\hline Minimum Score & 52.5 & 67.5 & 50 & 55 \\
\hline N-Gain Score & \multicolumn{2}{|c|}{0,38} & \multicolumn{2}{|c|}{0,16} \\
\hline
\end{tabular}

Based on the table above the average value before learning (pretest) in the experimental class is 66.79 and the control class is 65.23 , this indicates that the initial ability of each class is balanced. Then after learning in the experimental class using reciprocal teaching models assisted by macromedia flash the value of students 'concept understanding increased to 79.59 , as well as in the dick class there was an increase in the value of students' understanding of concepts after learning to 70.93. In addition, the results of the N-gain test showed that the experimental class received a score of 0.38 , this score was included in the category of the score range $0.3 \leq \mathrm{g} \leq 0.7$ with the category of medium criteria. Whereas the control class obtained a score of 0.16 included in the range of scores of $0.0000 \mathrm{~g} \leq 0.3$ with a low criteria category. To see more clearly the average value obtained from each class can be seen in the picture below

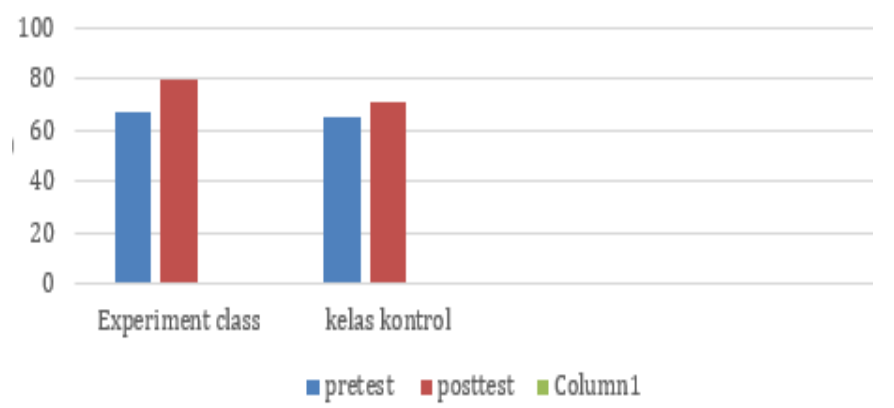

Fig. 1 Graph of conceptual understading between ekperiment-control class

Based on the fig. 1 it can be seen that the increase in value after learning in the experimental class or the class using learning with reciprocal teaching assisted by macromedia flash is higher than the class using conventional learning. An increase in grades in classes using reciprocal teaching assisted by macromedia flash in learning because the characteristics of this learning are able to encourage students to actively engage in learning. To find out the difference in the value of students' understanding of concepts between the experimental class and the control class can be seen in the test results table The independent sample t-test is answered 
Table 3. Difference Test Results of Independent Sample T-Test of Conceptual Understanding

Levene's Test for t-test for Equality of Means
Equality of
Variances

\begin{tabular}{lllllll}
\hline $\begin{array}{l}\text { Understanding } \\
\text { Concept Skill Scores }\end{array}$ & F & Sig. & t & Df & $\begin{array}{l}\text { Sig. } \\
\text { tailed })\end{array}$ & $\begin{array}{l}\text { Mean } \\
\text { Difference }\end{array}$ \\
& 3.021 & .087 & 5.670 & 62 & .000 & 8.43750 \\
\hline
\end{tabular}

Based on the results of the different independent sample t-test on the value of the concept understanding ability shows the value of sig. (2-tailed) of 0,000 , this means that the value is more than 0.05, so Ho is rejected and Hi is accepted, so that it can be interpreted that there are significant differences between the experimental class and the control class. This significant difference in influence indicates that learning using the reciprocal teaching model assisted by Macromedia Flash can improve student understanding of concepts better compared to classes that use conventional learning. The effect of the increasing grades on students can be influenced by learning activities that make them more active in learning activities because the reciprocal learning model encourages students to read and summarize the material that has been given the material provided. [15] states in her research revealed that reciprocal teaching can improve reading comprehension. In line with the results of research, [16] states that the application of biology learning models based on reading-concept map-team games tournaments, reading can help students to get cognitive learning outcomes for the better. In addition, reciprocal teaching also encourages students to ask questions about material that is not yet understood, and can trigger students to dialogue with each other. The results of the dialogue will construct ideas or ideas and students can better understand the concepts learned. [17] states that, dialogue can help individuals to develop understanding of concepts. [18] revealed that the benefits of this dialogue allow students to gain understanding, both from their roles as recipients of information and as people who convey information. The results of research conducted by [19] show that reciprocal teaching is able to improve learning outcomes because it helps in giving students the memory to understand the material. [20] individuals are better able to explore teaching material through dialogue in the classroom so that it can have an impact on knowledge that is not yet known to be more comprehensible and comprehensible. Likewise, according to [21] the advantages of reciprocal teaching is that one of them is able to improve students' academic achievement.

In addition, macromedia is used as a technology-based learning media that can contain text, animation, and video where students will more easily understand and increase interest in the material being taught because students will use their auditory and visual abilities during the learning process. [22] states that learning using macromedia flash has a better knowledge gain because individuals consider learning to use this material provided more clearly and not monotonous so that no boredom appears. In harmony with [23] states that classes using learning with Macromedia Flash have higher learning outcomes compared to classes using conventional methods. Macromedia flash when used as a learning medium will increase individual interest in learning so that it will have an impact on learning outcomes. In addition, macromedia flash can also load events which can then be displayed through simulations [24]. In line with the research, [25] states that the relationship of interest and learning outcomes is directly proportional, the higher an individual's interest in learning will have an impact on better learning outcomes. The 
results of this study are supported by [26] reciprocal teaching learning using multimedia capable of improving student learning outcomes.

\section{Conclusion}

Learning using the reciprocal teaching model assisted by macromedia flash is effective to improve students' understanding of the concept of class X SMA N 1 Jetis. This result is proven by the different independent sample $t$ test results with the significance value obtained 0,000 $<0.05$. Increased ability to understand concepts occur in each class. However, the class that uses a reciprocal teaching model assisted by macromedia flash has a higher N-Gain value of 0.38 (moderate), while the class N-Gain value using conventional methods is 0.16 with low criteria.

\section{References}

[1] Anderson, L.W and David R. K. Kerangka Landasan Untuk Pembelajaran, Pengajaran, dan Asesmen. Pustaka Pelajar,Yogyakarta (2010)

[2] Erman S. Strategi Pembelajran Matematika Kotemporer. UPI, Bandung (2003)

[3] Mills, S. Conceptual Understanding: A Concept Analysis. The Qualitative Report, 21 (3), 546 (2016)

[4] Ramlah, Dani F, Hamzah. Pengaruh Gaya Belajar Dan Keaktifan Siswa Terhadap Prestasi Belajar Matematika (Survey Pada SMP Negeri Di Kecamatan Klari Kabupaten Karawang). Jurnal Ilmiah Solusi Vol.1 No. 3. pp: 68-75 (2014)

[5] Afandi, M, Evi, C, Dan Oktarina, P. W. Model Dan Metode Pembelajaran Di Sekolah. UNISSULA Press, Semarang (2013)

[6] Arsyad, A. Media Pembelajaran. PT. Rajagrafindo Persada, Yogyakarta (2014)

[7] Jalinus, N, Ambiyar. Media Dan Sumber Belajar. KENCANA, Jakarta (2016)

[8] Huda, Miftahul. Model-Model Pengajaran Dan Pembelajaran. Pustaka Pelajar, Yogyakarta (2013)

[9] Palincsar A.S and Ann L. Brown. Reciprocal Teaching of Comprehension Fostering and Comprehension Monitoring Activities. Lawrence Erlbaum Associates, USA (1984)

[10] Bender, W.N. Differentiating Instruction for Students with Learning (2008)

[11] Aziz, Abdul. Metode Dan Model-Model Mengajar IPS. Alfabeta, Bandung (2007)

[12] Sunyoto. Adobe Flash $+\mathrm{XML}=$ Rich Multimedia Application. CV Andi Offset, Yogyakarta: (2010)

[13] Maya Yulianda Dan Sahyar. The Effect of Cooperative Learning Model Type Group Investigation (GI) Assisted Macromedia Flash, Adversity Quotient (AQ) On Students' Conceptual Knowledge. Journal of Education and Practice. Vol 8, No 18 pp. 71-76 (2017)

[14] Astuti, E Dan Heru Nurcahyo. Development of Biology Learning Media Based on Adobe Flash to Increase Interest and Conceptual Understanding. Journal of Physics: Conference Series. IOP Conf. Series: Journal of Physics: Conf. Series 1241 (2019) 012050

[15] Noriasih, Ni Ketut. Pengaruh Model Pembelajaran Reciprocal Teaching Terhadap Pemahaman Bacaan Ditinjau Dari Konsep Diri Akademik Siswa. Jurnal IKA. Vol 11. No. 2. pp. 27-45. 2013.

[16] Pangestuti, A. A, Hearawati, S Dan Siti Zubaidah. Penerapan Model Pembelajaran Biologi Berbasis Reading - Concept Map -Teams Games Tournaments Untuk Meningkatkan Kemampuan Berpikir Kritis Dan Hasil Belajar Kognitif Siswa Kelas X 
Ipa 4 Sma Laboratorium Um. Proceding Biology Education Conference. Vol 11. No. 1. pp 963-968 (2014)

[19] Zusje W. M. Warouw. Pembelajaran Reciprocal Teaching Dan Metakognitif(Rtm) Yang Memberdayakan Keterampilan Metakognitif Dan Hasil Belajar Biologi Siswa Smp. Jurnal Ilmu Pendidikan, Vol 17, No 2. pp. 162-171 (2010)

[20] Borich, Gary D. Effetive Teaching Methods. Englewood: Prentice-Hall, Inc (1992)

[21] Warsono, M.S Dan Hariyanto. Pembelajaran Aktif. PT Remaja Rosdakarya Offset, Bandung: (2014)

[22] Shanthy, T. Rajula; Thiagarajan, R. Interactive Multimedia Instruction Versus Traditional Training Programmes: Analysis of Their Effectiveness and Perception. Journal of Agricultural Educationa and Extension. Vol 17 No 5 Page: 459-472 (2011)

[17] Vygotsky, L. S. Mind in Society: The Development of The Higher Psychological Processes. Harvard University Press, Cambridge, MA (1978)

[18] Obiunu, J J. The Effects of Reciprocal Peer Tutoring on The Enhancement of Career Decision Making Process Among Secondary School Adolescents. Educational Research and Review. 3(7). 236-241. Available At: Http://Www.Academicjournals.Org/ERR. (2008)

[23] Ratna Kumala Dewi, Sri Haryani, Sri Wardani. The Influence of Guided Inquiry Learning Assisted Flash Application on Electrolyte Solution Materials Against the Results of Students. Vol 7 No 2. pp. 221 - 228 (2018)

[24] Rohana Hutahaean, Mara Bangun Harahap, Derlina. The Effect of Scientific Inquiry Learning Model Using Macromedia Flash on Student's Concept Understanding and Science Process Skills In Senior High School. IOSR Journal of Research \& Method in Education (IOSR-JRME). Volume 7, Issue 4 Ver. I. pp. 29-37 (2017)

[25] Daniyati, N., \& Sugiman, S. Hubungan Antara Kemampuan Verbal, Kemampuan Interpersonal, dan Minat Belajar Dengan Prestasi Belajar Matematika. PYTHAGORAS: Jurnal Pendidikan Matematika, 10(1). Pp. 50-60. (2015)

[26] Wiarta, I Wyn. Pengaruh Model Reciprocal Teaching (Pembelajaran Terbalik) Berbantuan Multimedia Terhadap Hasil Belajar Ips Siswa Kelas V Sd Gugus I Denpasar Selatan. Jurnal Mimbar PGSD Universitas Pendidikan Ganesha. Vol 2, No 1. (2014) 